\title{
Impact of roof geometry of an isolated leeward sawtooth roof building on cross-ventilation: Straight, concave, hybrid or convex?
}

\author{
J.I. Peren ${ }^{\mathrm{a}, \mathrm{b}, 1}$, T. van Hooff ${ }^{\mathrm{c}}$, R. Ramponi ${ }^{\mathrm{d}}$, B. Blocken ${ }^{\mathrm{b}, \mathrm{c}}$, B.C.C. Leite ${ }^{\mathrm{a}}$ \\ ${ }^{a}$ Civil Construction Engineering Department, Polytechnic School of the University of São Paulo - USP, São \\ Paulo, Brazil. \\ ${ }^{\mathrm{b}}$ Building Physics and Services, Eindhoven University of Technology, Eindhoven, The Netherlands. \\ ${ }^{\mathrm{c}}$ Building Physics Section, Leuven University, Leuven, Belgium. \\ ${ }^{\mathrm{d}}$ Architecture, Built Environment, Construction Engineering Department, Politecnico di Milano, \\ Milano, Italy.
}

\section{Graphical abstract}

\section{Impact of the leeward sawtooth-roof geometry}
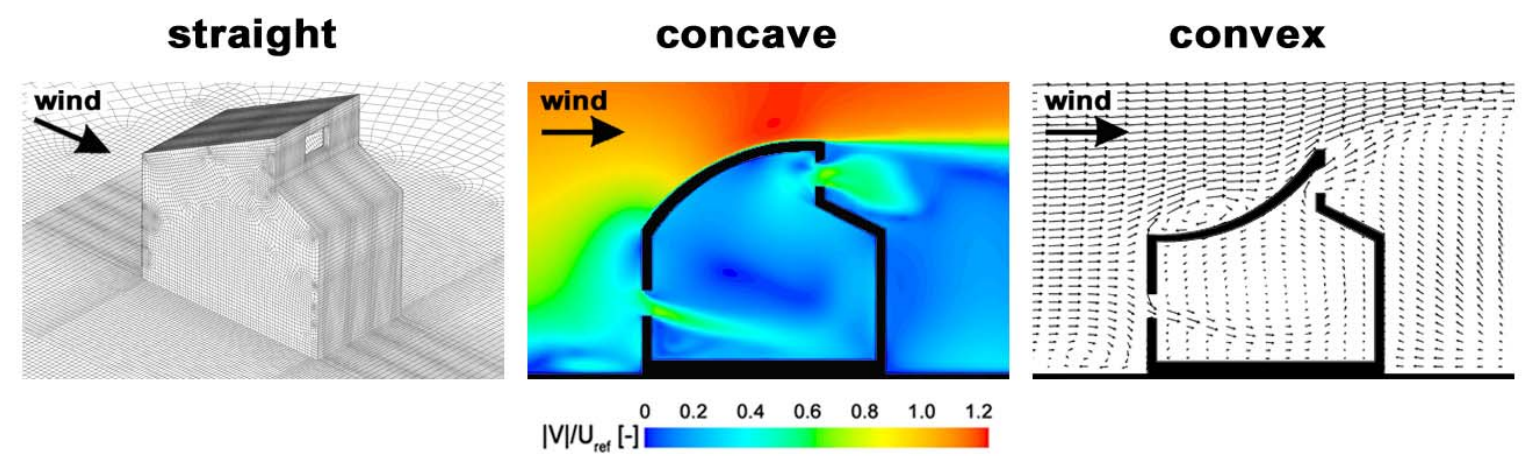

\footnotetext{
${ }^{1}$ Corresponding author: E-mail address: j.i.peren.montero@tue.nl; jiperen@usp.br. Tel.: +31 (0) 402473667. Fax +31 (0)40 243 8595. PO Box 513, $5600 \mathrm{MB}$, Eindhoven.
} 


\title{
Impact of roof geometry of an isolated leeward sawtooth roof building on cross-ventilation: Straight, concave, hybrid or convex?
}

\author{
J.I. Peren ${ }^{\mathrm{a}, \mathrm{b}, 2}$, T. van $\operatorname{Hooff}^{\mathrm{c}}$, R. Ramponi ${ }^{\mathrm{d}}$, B. Blocken ${ }^{\text {b,c }}$, B.C.C. Leite ${ }^{\mathrm{a}}$ \\ ${ }^{a}$ Civil Construction Engineering Department, Polytechnic School of the University of São Paulo - USP, São \\ Paulo, Brazil. \\ ${ }^{\mathrm{b}}$ Building Physics and Services, Eindhoven University of Technology, Eindhoven, The Netherlands. \\ ${ }^{\mathrm{c}}$ Building Physics Section, Leuven University, Leuven, Belgium. \\ ${ }^{d}$ Architecture, Built Environment, Construction Engineering Department, Politecnico di Milano, \\ Milano, Italy.
}

\begin{abstract}
The roof geometry of a leeward sawtooth roof building can have a large influence on the cross-ventilation flow. In this paper, five different leeward sawtooth roof geometries are evaluated using Computational Fluid Dynamics (CFD). The 3D CFD simulations are performed using the steady Reynolds-Averaged Navier-Stokes approach with the SST k- $\omega$ turbulence model to provide closure to the governing equations. The computational grid is based on a grid-sensitivity analysis and the computational model is successfully validated using PIV measurements for a generic isolated building from literature. The five different roof geometries that are studied include one straight and four curved roofs. The curved roofs can be subdivided in one concave, one hybrid (convex-concave) and two convex roof geometries. It is shown that a straight or convex roof geometry can maximize the underpressure in the wake of the building, where the outlet opening is located, which results in enhanced wind-driven cross-ventilation flow. Analysis of the results shows that for a normal wind incidence angle $\left(0^{\circ}\right)$ the straight and convex leeward sawtooth roof geometries can result in an increase of the volume flow rate by $13.0 \%, 12.5 \%$ and $12.3 \%$ respectively compared to a concave roof geometry. Furthermore, the increase of the indoor air velocity can be as high as $90 \%$ in the upper part of the occupied zone (at $\mathrm{h}=1.7 \mathrm{~m}$ above ground level) for convex versus concave roofs.
\end{abstract}

Keywords: Computational Fluid Dynamics (CFD); Building geometry; Natural ventilation; Leeward sawtooth roof geometry; Upward cross-ventilation

\section{Introduction}

The application of a sawtooth roof on buildings can contribute to a sustainable and healthy indoor environment as it can allow additional daylight and natural ventilation compared to a standard flat roof. Often, sawtooth roof buildings have openings in the lower part of the facade and upper-level openings near the roof top in the opposite facade. Using the upper-level openings located near the roof, the sawtooth roof can achieve more uniform and higher daylight intensity levels than the levels obtained by an opening located in the middle or in the lower part of a facade (Robbins 1986). The ventilation flow in a building with a sawtooth roof depends among others - on its orientation to the oncoming wind flow (Gandemer and Barnaud 1989). In a building with a leeward sawtooth roof, with supply openings in the bottom part of the windward facade and exhaust openings in the top part of the leeward facade, the wind-driven natural ventilation can be improved since the upward winddriven cross-ventilation flow can be assisted by possible buoyancy forces. Although the possible advantages of a leeward sawtooth roof in naturally ventilated buildings are known, the potential of buildings with a leeward sawtooth roof has not yet been extensively explored and this type of roof is still not applied on a large scale (Bittencourt 2006). In the past, several studies have been carried out on wind-induced loads on a sawtooth roof (Saathoff and Stathopoulos 1992, Stathopoulos and Saathoff 1992, Cui 2007), gable roof (Holmes 1994, St. Pierre et al. 2005, Quan et al. 2007) and arched roof (Holmes and Paterson 1993), however, these studies did not focus on the ventilation flow of the building as function of the different roof geometries. To the best knowledge of the authors, only one study by Fatnassi et al. (2006) investigated the impact of the roof shape for buildings with asymmetric opening positions and with respect to building ventilation. In addition, Kindangen et al. (1997a,

\footnotetext{
${ }^{2}$ Corresponding author: E-mail address: j.i.peren.montero@,tue.nl; jiperen@usp.br. Tel.: +31 (0) 402473667.
} Fax $+31(0) 40243$ 8595. PO Box 513, $5600 \mathrm{MB}$, Eindhoven. 
1997b) analyzed the effect of the roof shape on natural ventilation of the building, however, all the buildings in these studies had symmetric opening positions (openings located at the same level). Furthermore, these studies were not performed for a sawtooth roof building. In general, there is a lack of knowledge on the effect of roof geometry on the airflow pattern inside cross-ventilated buildings (Kindangen et al. 1997a), which is even more pronounced for buildings with a pitched roof (either a straight or curved geometry) and with asymmetric opening positions (inlet at lower part and outlet near roof level), such as sawtooth roof buildings. A systematic study is required to quantify the effect of a range of roof geometry parameters, e.g. roof inclination, roof shape, roof overhang, roof height, as the indoor airflow is the result of the combined effect of each of these geometrical parameters. A previous paper by the authors showed that a $27^{\circ}$ roof inclination angle with the outlet opening near the roof top can increase the volume flow rate through the building with $12 \%$ compared to a flat roof (Peren et al. 2015). However, more studies on this topic are needed to increase the understanding of the ventilation flow through these buildings, and to optimize the performance of leeward sawtooth roofs for this purpose.

The current paper analyzes the impact of straight, concave, hybrid (concave-convex) and convex leeward sawtooth roof geometries with a $27^{\circ}$ implicit roof inclination angle (i.e. the angle measured by drawing a straight line from the windward edge of the roof to the rooftop) and with asymmetric opening positions. Figure 1 shows the five leeward sawtooth roof geometries that are analyzed in this paper. The main objective is to analyze which type of roof geometry can increase the volume flow rate and indoor air velocities, and eventually also the air exchange, ventilation and heat removal effectiveness. In this study, the performance of each roof geometry is evaluated based on the volume flow rate through the building and the mean air velocity ratios in the occupied zone, measured at four different heights: $(\mathrm{h}=1.7 \mathrm{~m}, 1.1 \mathrm{~m}, 0.6 \mathrm{~m}$ and $0.1 \mathrm{~m})$, which are considered as reference for the evaluation of thermal comfort conditions of a seated or standing person, at a steady-state and moderate environment, i.e. where the environmental conditions are close to the thermal comfort standards proposed by ISO 7730/2005 (ISO 2005). Computational Fluid Dynamics (CFD) is employed with the 3D steady ReynoldsAveraged Navier-Stokes (RANS) equations with the SST k- $\omega$ turbulence model to provide closure. The simulations are based on grid-sensitivity analysis and on validation with previously published wind-tunnel measurements.

The results presented in this paper are part of a large research project on the enhancement of wind-driven cross-ventilation of residential buildings by adjusting the roof geometry. In this research project, among others, the effect of a range of sawtooth roof geometries (this paper), roof inclination angle (Péren et al. 2015), the addition of eaves, the size of the building and the roof span on the natural ventilation flow through a single-zone building is studied. For the sake of brevity and to enable a detailed assessment of the flow behavior in and around the building resulting from modification of a certain part of the building and/or roof geometry, this paper will focus on one part of the results obtained in this larger research project, namely the effect of roof geometry.

The building geometry and roof geometries that are analyzed using CFD are presented in Section 2. The validation study is addressed in Section 3. In Section 4 the computational settings are described and the results of the grid-sensitivity analysis and the horizontal homogeneity test are presented. Section 5 shows the results of the analysis of the different roof geometries. Section 6 (Discussion) and Section 7 (Conclusions) conclude this paper.

\section{Building and roof geometries}

Figure 1 shows a schematic representation of the five different roof geometries selected for this study. Each geometry is designated by a letter: A, B, C, D and E. Geometry A has a straight roof, whereas geometry B has a concave roof, $\mathrm{C}$ a hybrid convex-concave roof and the geometries $\mathrm{D}$ and $\mathrm{E}$ have convex roofs. Note that we adopt the definitions of "convex" and "concave" as used in the description of mathematical functions, where "a convex function is a continuous function whose value at the midpoint of every interval in its domain does not exceed the arithmetic mean of its values at the ends of the interval" (Wolfram Math World 2014). These five roof geometries have been chosen as fairly representative of the domain of different leeward sawtooth roof buildings, as schematically represented in Figure 2. This figure distinguishes between the main categories "convex - concave" on the horizontal axis and "curved - straight" on the vertical axis. In addition, the distance from the origin of the axes system is a measure of the roof inclination angle.

Figure 3 shows a front view, a vertical cross-section and a perspective view of the building with geometry A with its main dimensions. Apart from the roof shape, all five geometries have the same: (a) maximum roof height $(\mathrm{H}=5.7 \mathrm{~m})$; (b) building depth $(\mathrm{D}=6 \mathrm{~m})$; (c) building width $(\mathrm{W}=3 \mathrm{~m})$; (d) inlet and outlet opening size (corresponding to 5\% windward wall porosity); and, (e) inlet and outlet opening location (the outlet is located at $3 / 4$ D). Since all five buildings have different roof shapes, each building has a different internal volume $V: V_{A}=$ $54.18 \mathrm{~m}^{3}, \mathrm{~V}_{\mathrm{B}}=60.58 \mathrm{~m}^{3}, \mathrm{~V}_{\mathrm{C}}=53.52 \mathrm{~m}^{3}, \mathrm{~V}_{\mathrm{D}}=50.78 \mathrm{~m}^{3}$ and $\mathrm{V}_{\mathrm{E}}=49.91 \mathrm{~m}^{3}$. The distance from the ground to the bottom of the inlet and outlet opening is $1.42 \mathrm{~m}$ and $4.60 \mathrm{~m}$, respectively.

The roof inclination and the outlet opening position are important factors that influence the volume flow rate and the mean indoor air velocities, as pointed out in a previous paper by the authors (Peren et al. 2015). 
However, it is important to highlight that in all five geometries, the roof has an implicit roof inclination angle of $27^{\circ}$ and the outlet opening is located at exactly the same height near the roof top.

\section{CFD simulations: validation study}

Validation is imperative for CFD simulations in general, and more in particular for CFD simulations based on the 3D steady RANS equations (Franke et al. 2007, Tominaga et al. 2008, Blocken 2014). The CFD model employed in the current study has been validated extensively in a previous publication (Peren et al. 2015). In this section a general overview of the validation study will be provided. The reader is referred to Peren et al. (2015) for more information and an extensive analysis of the sensitivity of the results to a range of computational settings and parameters.

\subsection{Wind-tunnel measurements}

CFD validation is conducted using the PIV measurements of Karava et al. (2011) who studied wind-induced cross-ventilation for a generic isolated building model with asymmetric opening positions. The dimensions of the building model are $0.1 \times 0.1 \times 0.08 \mathrm{~m}^{3}$ ( $\mathrm{W} \times \mathrm{D} \times \mathrm{H} ; 1: 200$ scale), corresponding to full-scale dimensions of $20 \mathrm{x}$ $20 \times 16 \mathrm{~m}^{3}(\mathrm{~W} \times \mathrm{D} \times \mathrm{H})$, as shown in Figure 4. The openings have a fixed height of $0.018 \mathrm{~m}$ ( $3.6 \mathrm{~m}$ full scale) while the width varies to obtain different wall porosities. The validation study is conducted for the building model with an inlet opening at the bottom of the windward facade (with the center of the opening at $h=0.02 \mathrm{~m}$ ) and an outlet opening at the top of the opposite (leeward) facade (with the center of the opening at $\mathrm{h}=0.06 \mathrm{~m}$ ). The dimensions of the window are $0.046 \times 0.018 \mathrm{~m}^{2}(\mathrm{~W} \mathrm{x} \mathrm{H})$ and the resulting wall porosity is $10 \%$. The reduced-scale aerodynamic roughness length was $\mathrm{z}_{0}=0.025 \mathrm{~mm}$ corresponding to $0.005 \mathrm{~m}$ in full scale (Karava et al. 2011). The reference mean wind speed at building height $\left(\mathrm{z}_{\mathrm{ref}}\right)$ was $\mathrm{U}_{\mathrm{ref}}=6.97 \mathrm{~m} / \mathrm{s}$ and the turbulence intensity at building height was $10 \%$. The turbulence intensity was about $17 \%$ near ground level $(12 \mathrm{~mm})$ and $5 \%$ at gradient height $(738 \mathrm{~mm})$. The PIV measurements were conducted in the vertical center plane. For more information related to the wind-tunnel experiments the reader is referred to (Karava et al. 2011).

\subsection{CFD simulations: computational settings and parameters}

The computational model represents the reduced-scale model used in the experiments and follows the best practice guidelines by Franke et al. (2007) and Tominaga et al. (2008). The upstream length of the domain is reduced to 3 times the height of the building to limit the development of unintended streamwise gradients (Blocken et al. 2007a, 2007b, 2015). The dimensions of the domain are $0.9 \times 1.54 \times 0.48 \mathrm{~m}^{3}$ (W x D x H). The computational grid is created using the surface-grid extrusion technique by van Hooff and Blocken (2010a) and is shown in Figure $4 \mathrm{c}$ and $4 \mathrm{~d}$. The grid resolution resulted from a grid-sensitivity analysis yielding a fully structured hexahedral grid with 770,540 cells. The number of cells per building edge is 27 in the streamwise direction, 43 in the lateral direction and 61 in the vertical direction. The average height of the cells adjacent to the walls is $1 \mathrm{~mm}$ and the $\mathrm{y}^{+}$values of the cells near the wall inside the building are between 1 and 17. At the inlet of the domain the approach-flow vertical profiles (log-law mean wind speed $\mathrm{U}$, turbulent kinetic energy $\mathrm{k}$ and the specific dissipation rate $\omega$ ) are imposed, based on the incident vertical profiles of mean wind speed $U$ and longitudinal turbulence Intensity $\mathrm{I}_{\mathrm{U}}$ as measured in the wind-tunnel experiment. The turbulent kinetic energy $\mathrm{k}$ is calculated from the measured wind speed and turbulence intensity as $\mathrm{k}=\mathrm{a}\left(\mathrm{UI}_{\mathrm{U}}\right)^{2}$ where the coefficient "a" is equal to 0.5 according to a sensitivity analysis by the authors (Peren et al. 2015), assuming that the turbulent fluctuations in streamwise direction are much larger than those in lateral and vertical direction $\left(\sigma_{\mathrm{u}} \gg \sigma_{\mathrm{v}}\right.$ and $\sigma_{\mathrm{u}} \gg$ $\left.\sigma_{\mathrm{w}}\right)$.

The commercial CFD code ANSYS Fluent 12 is used to perform the simulations (ANSYS 2009). The 3D steady Reynolds-Averaged Navier-Stokes (RANS) equations are solved in combination with the shear-stress transport (SST) k- $\omega$ model (Menter 1994) and automated wall treatment (ANSYS 2009). This model is chosen based on previous validation studies of cross-ventilation (Peren et al. 2015, Ramponi and Blocken 2012). For pressure-velocity coupling the SIMPLE algorithm is used, pressure interpolation is second order and secondorder discretization schemes are used for both the convection terms and the viscous terms of the governing equations. Convergence is assumed to be obtained when all the scaled residuals leveled off and reached a minimum of $10^{-6}$ for $\mathrm{x}, \mathrm{y}$ momentum, $10^{-5}$ for $\mathrm{y}$ momentum and $10^{-4}$ for $\mathrm{k}, \varepsilon$ and continuity. As in previous studies of cross-ventilation of single-zone buildings (Peren et al. 2015, Ramponi and Blocken 2012), oscillatory convergence was observed. Oscillatory convergence implies that the scaled residuals do not reach an asymptote but show oscillatory behavior about an asymptotic value. This is caused by the intrinsic discrepancy of forcing an inherently unsteady flow to be predicted with a steady RANS model. It is important to note that this does not mean that the approach is flawed. On the contrary, if acknowledged and treated carefully and appropriately, as 
part of best practice in CFD (Blocken 2015), results from oscillatory convergence simulations with steady RANS can provide very accurate predictions of mean velocity fields, as shown in Ramponi and Blocken (2012) and Péren et al. (2015). Appropriate treatment refers to identification of the presence of oscillatory convergence and of averaging the results over a sufficient number of iterations. This is required because the results at different iterations actually correspond to different modes of the actual transient flow pattern (Blocken 2015). Note that the local oscillations in the velocities were in general within $10 \%$, where the highest oscillations occurred in areas with low velocities. Therefore, in order to obtain reliable stationary values of the solution variables in the entire flow domain, the results are monitored over 10,400 iterations and the variables are calculated by averaging over 400 iterations $(10,000-10,400)$, after the simulation reached a statistically stationary solution. More information on the presence and effects of oscillatory convergence can be found in Ramponi and Blocken (2012) and Blocken (2015).

\subsection{CFD validation results: comparison between CFD simulations and wind-tunnel measurements}

Figure $5 \mathrm{a}$ and $5 \mathrm{~b}$ display the mean velocity vector field in the vertical center plane obtained from PIV measurements and CFD simulations, respectively. It is observed that the CFD simulations correctly predict the most important flow features such as the standing vortex upstream of the building and the flow pattern inside the building. Figure $5 \mathrm{c}$ and $5 \mathrm{~d}$ compare the measured and computed streamwise wind speed ratio $\mathrm{U} / \mathrm{U}_{\text {ref }}$ along a horizontal line going through the middle of the windward opening and along a diagonal line, respectively. It can be concluded that the computational model provides a good agreement with the experimental data. The computational settings and parameters used in this validation study will therefore be used for the evaluation of natural ventilation flow of the buildings with different leeward sawtooth roof geometries, as presented in Section 4 (settings and parameters) and Section 5 (results).

\section{CFD simulations of different roof geometries: computational settings and parameters}

\subsection{Computational geometry, domain and grid}

The computational model of the building has dimensions as indicated in Section 2 and Figure 3.

The computational domain is depicted in Figure 6a and its dimensions are in accordance to the best practice guidelines by Franke et al. (2007) and Tominaga et al. (2008). To limit the development of unintended streamwise gradients the upstream length of the domain is reduced to 3 times the height of the building (Blocken et al. 2007a, 2007b, Blocken 2015). The dimensions of the domain are $88.35 \times 34.20 \times 30 \mathrm{~m}^{3}$ (W x D x H). Note that the simulations presented in this section are performed at full scale, which is in contrast to the validation study presented in Section 3, to allow a more easy interpretation of the results. In addition, if thermal effects will be included in future research, full-scale CFD simulations are imperative for dynamic similarity (Reynolds, Grashof and Archimedes numbers). To assess the influence of the scale at which the simulations of the different roof geometries are conducted, one simulation is also performed at reduced scale. The flow pattern and the qualitative results are identical to the results of the full-scale simulation, which can be attributed to the high building Reynolds numbers associated with the flow at both scales; at reduced-scale (1:15) corresponding to a building height similar to the one present in the validation study $(\approx 0.10 \mathrm{~m})$, the building Reynolds number equals 94,158, which is much larger than the recommended value of $\operatorname{Re}>11,000$ by Snyder (1981).

A non-conformal mesh is used in order to allow future CFD simulations for different wind incidence angles. The computational grid with hexahedral cells is created using the surface-grid extrusion technique by van Hooff and Blocken (2010a) that was also successfully employed in other studies for complex building geometries (e.g. (van Hooff en Blocken 2010b, Gousseau et al. 2011, Blocken et al. 2012, Janssen et al. 2013, Montazeri et al. 2013). The maximum stretching ratio is 1.2. A grid-sensitivity analysis is performed for geometry $\mathrm{D}$ based on three grids and the results are presented in Section 4.4. Figure 7 shows the vertical cross-sections and the computational grids of the five different roof geometries. The number of cells varies slightly for each geometry and ranges from 2.0 to 2.7 million cells.

\subsection{Boundary conditions}

At the inlet of the domain, the approach-flow mean wind speed profile and the profiles of the turbulent kinetic energy $(\mathrm{k})$ and the specific dissipation rate $(\omega)$ are imposed. The wind direction is perpendicular to the windward building facade. The inlet wind-velocity profile $\mathrm{U}(\mathrm{z})$ is defined according to the logarithmic law (Eq. $1)$ : 


$$
U(z)=\frac{u_{A B L}^{*}}{\kappa} \ln \left(\frac{z+z_{0}}{z_{0}}\right)
$$

with $\mathrm{z}_{0}=0.1 \mathrm{~m}, \mathrm{u}_{\mathrm{ABL}}^{*}$ is the ABL friction velocity, $\kappa$ is the von Karman constant $(0.42)$ and $\mathrm{z}$ the height coordinate. The value of $\mathrm{u}_{\mathrm{ABL}}{ }^{\mathrm{AB}}$ is determined based on the values of the reference velocity $\left(\mathrm{U}_{\text {ref }}\right)$ at building height $(H)$, which are $U_{\text {ref }}=12.48 \mathrm{~m} / \mathrm{s}, H=5.7 \mathrm{~m}$, yielding a building Reynolds number of 500,000 . Note that the aerodynamic roughness length is higher than in the validation study to represent a more realistic wind velocity profile, corresponding to "roughly open country" according to the updated Davenport roughness classification by Wieringa (1992). The turbulent kinetic energy $\mathrm{k}$ is calculated from the mean wind speed $\mathrm{U}(\mathrm{z})$ and the streamwise turbulence intensity $\mathrm{I}_{\mathrm{u}}(\mathrm{z})$ (with a value of $15 \%$ at the top of the building model (at $\mathrm{z}_{\mathrm{ref}}$ ) and $45 \%$ at ground level) by Eq. (2):

$$
k(z)=a\left(I_{U}(z) U(z)\right)^{2}
$$

In this equation "a" is taken equal to 0.5 as in the validation study. The specific dissipation rate $\omega$ is given by Eq. (3), where $\mathrm{C}_{\mu}$ is an empirical constant $(=0.09)$, and $\varepsilon$ is the turbulence dissipation rate given by Eq. (4).

$$
\begin{aligned}
& \omega(z)=\frac{\varepsilon(z)}{C_{\mu} k(z)} \\
& \varepsilon(z)=\frac{u_{A B L}^{* 3}}{\kappa\left(z+z_{0}\right)}
\end{aligned}
$$

The SST k- $\omega$ model uses an automated wall treatment (ANSYS 2009) for the ground and building surfaces, which automatically switches between low-Reynolds number modelling and standard wall functions (Launder and Spalding 1974) in conjunction with the sand-grain based roughness $\left(\mathrm{k}_{\mathrm{s}}\right)$ modification defined by Cebeci and Bradshaw (1977) depending on the mesh resolution near the wall. For the ground surfaces, the values of the roughness parameters, i.e. the sand-grain roughness height $\left(\mathrm{k}_{\mathrm{s}}=0.14 \mathrm{~m}\right)$ and the roughness constant $\left(\mathrm{C}_{\mathrm{s}}=7\right)$, are determined based on the relationship with the aerodynamic roughness length $\mathrm{z}_{0}$ derived by Blocken et al. (2007a):

$$
k_{s}=\frac{9.793 z_{0}}{C_{s}}
$$

For the building surface the value of the sand-grain roughness is zero $\left(\mathrm{k}_{\mathrm{S}}=0 \mathrm{~m}\right)$, which corresponds to a smooth wall. This choice was based on previous parametric CFD studies with $\mathrm{k}_{\mathrm{S}}$ values of $0 \mathrm{~m}, 0.01 \mathrm{~m}$ and $0.05 \mathrm{~m}$, which showed no notable differences for the ventilation flow rates (van Hooff and Blocken 2010b). At the outlet plane, zero static gauge pressure is applied and at the top and lateral sides of the domain a symmetry condition is imposed, i.e. zero normal velocity and zero normal gradients of all variables. A simulation in an empty computational domain is performed to assess the extent of unintended streamwise gradients (i.e. horizontal inhomogeneity) in the vertical mean-wind speed profile and the turbulence profiles. Figure 8 shows the vertical profiles of $\mathrm{U}, \mathrm{k}$ and $\omega$ at the inlet (inlet profiles) and at the location where the building will be positioned (incident profiles). It can be seen that streamwise gradients are absent for the mean wind speed profile. The profiles of $\mathrm{k}$ and $\omega$ do show some streamwise gradients, however, for $\mathrm{k}$ up to $60 \%$ at building height. This is a large difference. However, this does not compromise the value of this study, for several reasons: (i) First, a similar decay will also occur in reality when an approaching atmospheric boundary layer flow over rough terrain suddenly encounters a much smoother terrain upstream of the building. As such, this decay is a realistic occurrence. (ii) Second, the focus of this study is on the comparison between the performance of difference roof geometries. As such, the comparative evaluation is more important than the absolute values obtained.

\subsection{Solver settings}

The commercial CFD code ANSYS Fluent 12 (2009) and the 3D steady RANS equations are employed for the analysis of the different roof geometries. Apart from the computational geometry and grid, the computational settings, parameters and the convergence criteria are taken equal to those of the numerical validation study as presented in Section 3.2. 
A grid-sensitivity analysis is performed for geometry D based on three grids: (1) a coarse grid with 1,012,336 cells; (2) a basic grid with 1,961,524 cells; and (3) a fine grid with 4,028,476 cells. The two additional grids (basic and the fine grid) are constructed by refining the coarse grid with about a linear factor $2^{1 / 3}$. Figure 9 shows dimensionless velocity magnitude $\left(|\mathrm{V}| / \mathrm{U}_{\text {ref }}\right)$ at a horizontal line through the middle of the windward opening of the building obtained with the three different grids. It is shown that the basic grid provides nearly gridindependent results. Also in terms of ventilation flow rates there are only very small differences between the three different grids; i.e. the volume flow rates are within $1.6 \%$ (coarse grid) and $1.1 \%$ (basic grid) compared with the finest grid. Therefore, it is concluded that the basic grid is a suitable grid for this study and it is used for the other simulations presented in this paper. The average height of the wall-adjacent cells in this basic grid is $0.07 \mathrm{~m}$ and the $\mathrm{y}^{+}$values of the cells inside the building are between 1 and 35 .

\section{CFD simulations of different roof geometries: results}

The ventilative performance of the five different roof geometries is assessed based on the volume flow rate through the openings and the average dimensionless velocity magnitude $\left(\mid \mathrm{V} / / \mathrm{U}_{\text {ref }}\right)$ along four horizontal lines at four different heights $(\mathrm{h}$ ) from the ground floor; i.e. $\mathrm{h}=1.7 \mathrm{~m}, 1.1 \mathrm{~m}, 0.6 \mathrm{~m}$, and $0.1 \mathrm{~m}$. In addition, the airflow pattern around and inside the building is analyzed.

\subsection{Volume flow rate}

Figure 10a shows the volume flow rate in percentage (\%), in which geometry B is taken as the reference case $(=100 \%)$ since it has the lowest volume flow rate $\left(=2.54 \mathrm{~m}^{3} / \mathrm{s}\right)$. The volume flow rate through the inlet opening of the building is obtained by taking the surface integral of the velocity at the inlet opening surface. The building with roof geometry A and the buildings with a convex roof geometry (i.e. D and E) have almost equal volume flow rates, which are respectively $13.0 \%, 12.5 \%$ and $12.3 \%$ higher than that of geometry $\mathrm{B}$. The building with a hybrid convex-concave roof geometry (geometry $\mathrm{C}$ ) has a $8.4 \%$ higher volume flow rate than geometry $\mathrm{B}$. Figure 10b shows the area-weighted average of the pressure coefficient $\left(\mathrm{C}_{\mathrm{P}}\right)$ at the outlet opening surface for all five geometries. It can be seen that the roof geometries which result in higher volume flow rates are the geometries with higher underpressure values (i.e. straight roof geometry A with $\mathrm{C}_{\mathrm{P}}=-0.27$; and convex roof geometries $D$ with $C_{P}=-0.29$ and $E$ with $C_{P}=-0.29$ ). There is, as expected, a clear relation between the average pressure coefficient and the volume flow rate, as depicted in Figure 10.

\subsection{Indoor airflow}

The impact of the roof shape on the dimensionless velocity magnitude $\left(\mid \mathrm{V} / / \mathrm{U}_{\text {ref }}\right)$, along four horizontal lines located at a height h of $1.7 \mathrm{~m}, 1.1 \mathrm{~m}, 0.6 \mathrm{~m}$ and $0.1 \mathrm{~m}$ from the internal floor, as shown in Figure 11, is evaluated. The four heights correspond to the positions of the parts of the body (head, chest, legs and feet) of a seated or standing person, which are reference heights for thermal comfort evaluation in an occupied zone of a building (ISO 2005). Figure 11b shows that the five different roof geometries result in roughly the same velocity profiles at $\mathrm{h}=1.7 \mathrm{~m}$. However, locally, large velocity differences can occur; up to $90 \%$ between geometry $\mathrm{D}$ and $\mathrm{B}$ at $\mathrm{x} / \mathrm{D}=0.7$. At $\mathrm{h}=1.1 \mathrm{~m}$, geometries $\mathrm{A}$ and $\mathrm{D}$ have slightly higher velocities from $0.15<\mathrm{x}<0.80$. (Fig. 11c). At $\mathrm{h}=0.6 \mathrm{~m}$, geometry $\mathrm{E}$ has the highest local velocity from $0.30<\mathrm{x}<0.70$, but also the lowest from 0.0 $<\mathrm{x}<0.3$ and from $0.85<\mathrm{x}<1.00$ (Fig. 11d). In general, at $\mathrm{h}=1.7 \mathrm{~m}, 1.1 \mathrm{~m}$ and $0.6 \mathrm{~m}$, the concave geometries $\mathrm{B}$ and $\mathrm{C}$ result in lower indoor air velocities (Fig. 11b, 11c and 11d), however, at $\mathrm{h}=0.1 \mathrm{~m}$ geometries $\mathrm{B}$ and $\mathrm{C}$ have higher velocities than $\mathrm{A}, \mathrm{D}$, and $\mathrm{E}$ (Fig. 11e).

\subsection{Airflow pattern}

In order to further analyze the effect of the roof geometry on the flow pattern around and inside the building, Figure 12 shows contours of the pressure coefficient $\left(C_{P}\right)$ and of the dimensionless velocity magnitude $\left(\mid \mathrm{V} / / \mathrm{U}_{\text {ref }}\right)$. The pressure coefficient is calculated as:

$$
C_{P}=\frac{\left(P-P_{0}\right)}{\left(0.5 \rho U_{r e f}^{2}\right)}
$$


where $P$ is the static pressure, $P_{0}$ the reference static pressure, $\rho$ the density of air $\left(=1.225 \mathrm{~kg} / \mathrm{m}^{3}\right.$ : International Standard Atmosphere (ISA); dry air, $\theta_{\mathrm{a}}=15^{\circ} \mathrm{C}, \mathrm{p}_{0}=101,325 \mathrm{~Pa}$ (ISO 1975) and $\mathrm{U}_{\text {ref }}$ is the approach-flow wind speed at building height $\left(\mathrm{U}_{\mathrm{ref}}=12.48 \mathrm{~m} / \mathrm{s}\right.$ at $\left.\mathrm{z}_{\mathrm{ref}}=5.7 \mathrm{~m}\right)$. Figures $12 \mathrm{~h}$ and $12 \mathrm{j}$ show that the roofs with a convex geometry (D and E) show an increase of the size (height) of the wake behind the building, resulting in lower pressures in the wake region (Fig. 12g,i) and a larger pressure difference over the building. As a consequence, the convex geometries have a higher volume flow rate through the inlet opening. In geometry B, with a fully curved concave roof shape, the flow stays attached along the entire roof surface. Figures $12 \mathrm{~d}$ and $12 \mathrm{f}$ show a strong flow acceleration on the roof of the geometries B and C. Under a normal wind incidence angle, a concave roof geometry, such as B, reduces the ventilation potential due to a decrease of the size of the underpressure zone and the magnitude of the underpressure behind the building (wake region), compared to for example geometry E. On the other hand, geometry A and the convex geometries D and E, increase the size and magnitude of the underpressure zone in the wake region (see Fig. 12a,g,i) and, as a consequence, the volume flow rate is around $13 \%$ higher than for geometry B, as shown in Figure 10. Note that in addition to geometry B, geometry A also has no, or at least a very limited, flow separation at the windward roof edge (Fig. 12a,b).

\subsection{Comparison between concave (B) and convex (E) roof geometry}

The impact of a concave and a convex roof geometry on indoor air velocity is studied in more detail by focusing on geometry B (concave) and geometry E (convex). Figure 13 shows the mean velocity vectors in the vertical center plane for both geometries. Figure 13a shows that the airflow remains attached to the roof surface of the concave geometry B, and the stagnation point is slightly elevated to the top of the windward facade, compared with the convex geometry E (see also Fig. 12c). Figure 13b shows the separation bubble on the roof for geometry E. The largest differences in the flow pattern around the building can be seen above the roof and in the wake region. As mentioned before, in geometry B the flow remains attached to the roof which results in a horizontally directed flow above the downstream part of the sawtooth roof. The flow above the roof in geometry $\mathrm{E}$ is guided upwards by the convex curved roof, resulting in a strong upward flow and a larger wake region. The flow through the outlet opening can be seen as a diagonally directed jet flow, with somewhat larger velocities than in geometry B. As a result, the volume flow rate for geometry E is $12.3 \%$ larger than for geometry B.

In addition to the roof geometry, there are two other factors that might have an influence on the ventilation performance of the roof geometries in general, and of roof geometry B and E in particular; (1) the size of the internal volume, and (2) the different geometry above the upper part of the outlet opening, i.e. the small piece of wall above the outlet opening in geometries A, B and C (see Fig. 1 and dashed circle in Fig. 13a). The internal volume of geometry B is clearly larger than that of geometry E, which might influence the flow through the building (different internal resistance). Furthermore, in geometry E, the upper part of the outlet opening coincides with the lower part of the roof (= ceiling) (see dashed circle in Fig. 13b), consequently, there is no 'potential obstruction' to the outgoing flow. In geometry B on the other hand, there is an 'obstruction' above the outlet opening (Fig. 13a) which might block the flow and influence the volume flow rate through the building. To assess both effects, an additional simulation has been conducted of geometry B-E (see Fig. 14a), which is a combination of geometry B and E; i.e. external shape of geometry B and internal shape of geometry E. This geometry therefore has the same internal volume as geometry E and does not have the internal obstruction above the outlet opening. Figure $14 \mathrm{~b}, \mathrm{~d}$ shows the flow through the building for geometry B-E, indicating that the flow indeed does not experience an internal obstruction near the outlet opening for this geometry. This additional simulation shows that the volume flow rate for geometry B-E is only $1.2 \%$ higher than the volume flow rate for geometry B. The underpressure near the outlet opening is almost equal as well (Fig. 12c, Fig. 14c); the $C_{P}$ value is -0.18 for geometry B and -0.17 for geometry B-E. Therefore, it can be concluded that in this particular case both factors, i.e. internal volume and vertical obstruction above the outlet opening, based on a combined assessment of both factors, do not significantly affect the results; the higher volume flow rate for geometry $\mathrm{E}$ compared to geometry B can almost completely be attributed to the external shape of the roof and its effect on the external wind flow. Figure 15 shows the percentage increase of the indoor velocity magnitude $|\mathrm{V}|\left(|\mathrm{V}|_{\mathrm{E}^{-}}\right.$ $\left.|\mathrm{V}|_{\mathrm{B}}\right) /\left(\left.\mathrm{V}\right|_{\mathrm{B}}\right.$ ) for geometry $\mathrm{E}$ compared to the wind speed for geometry $\mathrm{B}$, along the four lines defined earlier at $\mathrm{h}=$ $1.7 \mathrm{~m}, 1.1 \mathrm{~m}, 0.6 \mathrm{~m}$ and $0.1 \mathrm{~m}$. This allows a direct comparison between geometry B and E. Figure 15a shows that the increase in velocity in geometry $\mathrm{E}$ at $\mathrm{h}=1.7 \mathrm{~m}$ can be as large as $70 \%$ between $0.60<\mathrm{x} / \mathrm{D}<0.65$, while the velocities are lower than $\mathrm{B}$ from $0.00<\mathrm{x} / \mathrm{D}<0.25$ and from $0.30<\mathrm{x} / \mathrm{D}<0.55$. Figure $15 \mathrm{~b}$ shows that the indoor velocity at $\mathrm{h}=1.1 \mathrm{~m}$ is increased by up to $18 \%$ in geometry $\mathrm{E}$ between $0.00<\mathrm{x} / \mathrm{D}<0.40$ and $0.75<\mathrm{x} / \mathrm{D}$ $<0.90$ and decreased between $0.40<\mathrm{x} / \mathrm{D}<0.75$. The indoor air velocity at $\mathrm{h}=0.6 \mathrm{~m}$ is increased in the middle region (between $0.30<\mathrm{x} / \mathrm{D}<0.85$ ) (Fig. 15c). Finally, Figure 15d shows that the indoor velocities are higher in geometry $\mathrm{B}$ at almost the entire line at $\mathrm{h}=0.1 \mathrm{~m}$. Although geometry B has the lowest volume flow rate through the building, it can be seen that the velocities inside the building are higher than for geometry $\mathrm{E}$ at several locations. The fact that large differences in indoor air velocities are present between the buildings with different roof geometries, in this case between B and E, is in line with the observations of Kindangen et al. (1997a), who 
pointed out that the roof geometry directly affects the indoor airflow pattern in general, and the velocity magnitude in particular. However, the research by Kindangen et al. (1997a) focused on a position of the outlet opening at the same level as the inlet opening, which is different from the present study.

\section{Discussion}

The main goal of this paper is evaluate the impact of leeward sawtooth roof geometries on wind-driven crossventilation under normal wind incidence angle. Five leeward sawtooth roof geometries are evaluated: a straight roof (A), a concave roof (B), a hybrid convex-concave roof (C) and two convex roofs (D, E). The impact on ventilation performance is analyzed in terms of volume flow rate and indoor air velocities. In order to quantify the impact of the differences in internal volume for the different roof geometries, the concave roof geometry B and the convex roof geometry E are combined to generate the new geometry B-E. Finally, two of the analyzed roof geometries, a concave shape (B) and a convex shape (E), are compared more in detail with respect to the indoor air velocity. It is important to mention the limitations of the current study, which should be addressed in future research:

- This analysis considered a simplified isolated single zone building. The impact of other building parameters such as eaves (overhang) and internal layout should be taken into account in future research.

- The impact of wind incidence angles different than $0^{\circ}$ should be considered as well, since this can influence the ventilation performance of the different geometries. For more oblique wind incidence angles it might be necessary to resort to unsteady simulations, such as Large Eddy Simulations (LES) or Detached Eddy Simulation (DES), to accurately predict the volume flow rates through the openings resulting from unsteady flow features (e.g. Jiang and Chen 2001, Wright and Hargreaves 2006).

- Due to the use of steady RANS in this study, only average pressures are obtained, which result in an average volume flow rate. To analyze the effect of pressure fluctuations on the average volume flow rate, future research will include DES or LES simulations from which the calculated volume flow rates will be compared to the results of the steady RANS simulations.

- All geometries analyzed have a different internal volume due to differences in the roof geometry. In order to further evaluate the impact of the internal volume a new building geometry (geometry B-E) was evaluated. This new geometry results from the combination of the external concave shape of geometry B and the internal convex shape of geometry E, yielding a building geometry with the same internal volume as geometry $\mathrm{E}$. The results show a very small impact of the internal volume and the obstruction near the outlet opening on the volume flow rate through the building (1.2\% increase). Moreover, it must be noted that it is nearly impossible to keep all geometrical parameters constant when changing the roof geometry.

- Future work can also include an analysis of the performance of a double-span roof with the same roof geometries in addition to the single-span roof as studied in this paper.

\section{Conclusions}

This paper presents the performance of five different roof geometries for an isolated leeward sawtooth roof building, with the aim to optimize the upward cross-ventilation flow. The analysis is performed using 3D steady CFD simulations with the RANS approach and the SST k- $\omega$ model. The simulations are based on grid-sensitivity analysis and on validation using Particle Image Velocimetry (PIV) wind-tunnel measurements. The main conclusions of this paper are summarized below:

- The computational model is successfully validated using wind-tunnel measurements from literature.

- The internal airflow and the volume flow rate show a clear dependency on the roof geometry.

- For a normal wind incidence angle $\left(0^{\circ}\right)$, the convex roof geometries (D and $\mathrm{E}$ ) and the straight roof geometry (A) result in higher volume flow rates than concave (B) and hybrid convex-concave (C) roof geometry. The volume flow rates for geometry A, D and E are about 13\% higher than that of geometry $\mathrm{B}$, which shows the lowest performance.

- Analysis of the additional roof geometry (B-E), which consisted of the internal shape of geometry $\mathrm{E}$ and the external shape of geometry B showed that the size of the internal volume of the building does not significantly influence the volume flow rate through the building; the volume flow rate is only $1.2 \%$ larger for geometry B-E than for geometry B. In addition, this simulation showed that the vertical obstruction above the outlet opening does not affect the results much either.

- The roof geometry is an important design parameter to maximize the size and magnitude of the underpressure zone in the wake of the building and the pressure difference over the building, and consequently the volume flow rate through the building. A roof that directs the external wind flow 
behind the building upwards will result in a larger underpressure zone and larger magnitude of the underpressure, and consequently in higher volume flow rates.

- The indoor air velocities depend on the roof geometry, although this dependency is less clear. For instance, a comparison of geometry B (lowest volume flow rate) with geometry E (one of the highest volume flow rates) shows that the indoor air velocity in the occupied zone in geometry B is higher than in geometry E at several locations, and the other way around at some other locations. Therefore, it is not easy to draw a firm conclusion on the performance of the different roof geometries with respect to the indoor air velocities.

\section{Acknowledgements}

This work was supported by The Coordination for the Improvement of Higher Level Personnel (CAPES), Brazil, The Polytechnic School of the University of São Paulo (USP), Brazil, The Secretary of Education, Science, Research and Technology of Panama (SENACYT), Panama and the unit Building Physics and Services of the Department of the Built Environment at Eindhoven University of Technology in the Netherlands.

Twan van Hooff is currently a postdoctoral fellow of the Research Foundation - Flanders (FWO) and acknowledges its financial support (project FWO 12R9715N).

\section{References}

ANSYS. Fluent 12 user's guide. Lebanon: Fluent Inc. 2009.

Bittencourt L. Introdução à ventilação natural nas edificações. Editora da Universidade Federal de Alagoas EDUFAL, Maceio, Brasil; 2006.

Blocken B. 50 years of Computational Wind Engineering: Past, present and future. J Wind Eng Ind Aerodyn 2014;129:69-102. doi:10.1016/j.jweia.2014.03.008.

Blocken B. Computational Fluid Dynamics for Urban Physics: Importance, scales, possibilities, limitations and ten tips and tricks towards accurate and reliable simulations. Build Environ 2015; doi:10.1016/j.buildenv.2015.02.015.

Blocken B, Stathopoulos T, Carmeliet J. CFD simulation of the atmospheric boundary layer: wall function problems. Atmos Environ 2007a;41:238-52. doi:10.1016/j.atmosenv.2006.08.019

Blocken B, Carmeliet J, Stathopoulos T. CFD evaluation of wind speed conditions in passages between parallel buildings - effect of wall-function roughness modifications for the atmospheric boundary layer flow. J Wind Eng Ind Aerodyn 2007b;95:941-62. doi:10.1016/j.jweia.2007.01.013.

Blocken B, Janssen WD, van Hooff T. CFD simulation for pedestrian wind comfort and wind safety in urban areas: General decision framework and case study for the Eindhoven University campus. Environ Model Softw 2012;30:15-34. doi:10.1016/j.envsoft.2011.11.009.

Cebeci T, Bradshaw P. Momentum transfer in boundary layers. Hemisphere Publishing Corp. New York: 1977.

Cui B. Wind Effects on Monosloped and Sawtooth Roof. PhD Thesis. Clemson University, 2007.

Fatnassi H, Boulard T, Poncet C, Chave M. Optimisation of Greenhouse Insect Screening with Computational Fluid Dynamics. Biosyst Eng 2006;93:301-12. doi:10.1016/j.biosystemseng.2005.11.014.

Franke J, Hellsten A, Schlünzen H, Carissimo B. Best practice guideline for the CFD simulation of flows in the urban environment. Brussels: COST Office 2007.

Gandemer J, Barnaud G. Ventilation Naturelle des Habitations sous Climat Tropical Humide: Approach Aerodynamique. Nantes: CSTB; 1989.

Gousseau P, Blocken B, Stathopoulos T, van Heijst GJF. CFD simulation of near-field pollutant dispersion on a high-resolution grid: A case study by LES and RANS for a building group in downtown Montreal. Atmos Environ 2011;45:428-38. doi:10.1016/j.atmosenv.2010.09.065.

International Organization for Standardization. Standard Atmosphere, ISO 2533:1975, 1975.

Janssen WD, Blocken B, van Hooff T. Pedestrian wind comfort around buildings: Comparison of wind comfort criteria based on whole-flow field data for a complex case study. Build Environ 2013;59:547-562.

Jiang Y, Chen Q. Study of natural ventilation in buildings by large eddy simulation. J Wind Eng Ind Aerodyn 2001;89(13):1155-1178.

Holmes JD. Wind pressures on tropical housing. J Wind Eng Ind Aerodyn 1994;53:105-23. doi:10.1016/01676105(94)90021-3.

Holmes JD, Paterson DA. Mean wind pressures on arched-roof buildings by computation. J Wind Eng Ind Aerodyn 1993;50:235-42. doi:10.1016/0167-6105(93)90078-3.

International Organization for Standardization. Ergonomics of the thermal environment - Analytical determination and interpretation of thermal comfort using calculation of the PMV and PPD indices and 
local thermal comfort criteria (ISO 7730:2005). European Committee for Standardization, Brussels, Belgium; 2005.

Karava P, Stathopoulos T, Athienitis AK. Airflow assessment in cross-ventilated buildings with operable façade elements. Build Environ 2011;46:266-79. doi:10.1016/j.buildenv.2010.07.022.

Kindangen J, Krauss G, Depecker P. Effects of Roof Shapes on Wind-Induced Air Motion Inside Buildings. Build Environ 1997a;32:1-11.

Kindangen JI. Window and roof configurations for comfort ventilation. Build Res Inf 1997b;25:218-25. doi:10.1080/096132197370345.

Launder BE, Spalding DB. The numerical computation of turbulent flows. Comput Methods Appl Mech Eng 1974;3:269-89. doi:10.1016/0045-7825(74)90029-2.

Menter FR. Two-equation eddy-viscosity turbulence models for engineering applications. AIAA J 1994;32:1598-605.

Montazeri H, Blocken B, Janssen WD, van Hooff T. CFD evaluation of new second-skin facade concept for wind comfort on building balconies: Case study for the Park Tower in Antwerp. Build Environ 2013;68:179-92. doi:10.1016/j.buildenv.2013.07.004.

Peren JI, van Hooff T, Leite BCC, Blocken B. CFD simulation of cross-ventilation of a generic isolated building with asymmetric opening positions: impact of roof angle and opening location. Build Environ 2015;85: 263-276.

Quan Y, Tamura Y, Matsui M. Mean wind pressure coefficients on surfaces of gable-roofed low-rise buildings. Adv Struct Eng 2007;10:259-71. doi:10.1260/136943307781422253.

Ramponi R, Blocken B. CFD simulation of cross-ventilation for a generic isolated building: Impact of computational parameters. Build Environ 2012;53:34-48. doi:10.1016/j.buildenv.2012.01.004.

Robbins CL. Daylighting: design and analysis. Van Nostrand Reinhold Company; 1986.

Saathoff P, Stathopoulos T. Wind loads on buildings with sawtooth roofs . J Struct Eng 1992;118:429-446.

Snyder WH. Guideline for fluid modeling of atmospheric diffusion. U.S. Environmental Protection Agency Report No. EPA-600/8-81-009. 1981

Stathopoulos T, Saathoff P. Codification of Wind pressure coefficients for sawtooth roofs. J Wind Eng Ind Aerodyn 1992;43:1727-38. doi:16/0167-6105(92)90584-W.

St. Pierre LMS, Kopp GA, Surry D, Ho TCE. The UWO contribution to the NIST aerodynamic database for wind loads on low buildings: Part 2. Comparison of data with wind load provisions. J Wind Eng Ind Aerodyn 2005;93:31-59. doi:10.1016/j.jweia.2004.07.007.

Tominaga Y, Mochida A, Yoshie R, Kataoka H, Nozu T, Yoshikawa M, et al. AIJ guidelines for practical applications of CFD to pedestrian wind environment around buildings. J Wind Eng Ind Aerodyn 2008;96:1749-61. doi:10.1016/j.jweia.2008.02.058.

van Hooff T, Blocken B. Coupled urban wind flow and indoor natural ventilation modelling on a high-resolution grid: A case study for the Amsterdam Arena stadium. Environ Model Softw 2010a;25:51-65. doi:10.1016/j.envsoft.2009.07.008.

van Hooff T, Blocken B. On the effect of wind direction and urban surroundings on natural ventilation of a large semi-enclosed stadium. Comput Fluids 2010b;39:1146-55. doi:10.1016/j.compfluid.2010.02.004.

van Hooff T, Blocken B, Aanen L, Bronsema B. A venturi-shaped roof for wind-induced natural ventilation of buildings: Wind tunnel and CFD evaluation of different design configurations. Build Environ 2011;46:1797-807. doi:16/j.buildenv.2011.02.009.

Wieringa J. Updating the Davenport roughness classification. J Wind Eng Indus Aerodyn 1992;41(1):357-368.

Wolfram MathWorld. http://mathworld.wolfram.com/ConvexFunction.html. Retrieved on 01/12/2014.

Wright NG, Hargreaves DM. Unsteady CFD simulations for natural ventilation. Int J Vent 2006;5(1):13-20. 


\section{FIGURES}

\section{Leeward sawtooth-roof cases}

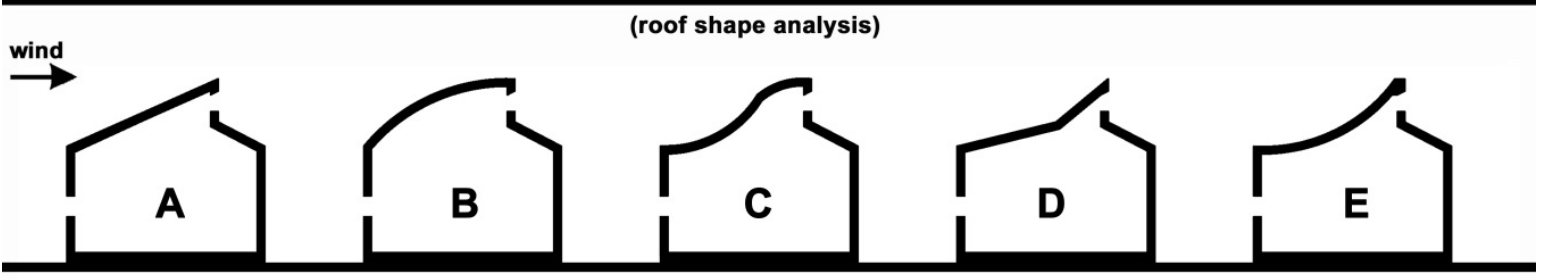

Fig. 1. Leeward roof shapes analyzed in this paper. All the geometries have the same plan dimensions, the same maximum roof height but different internal volumes.

\section{Leeward sawtooth-roof geometry: selection criteria}

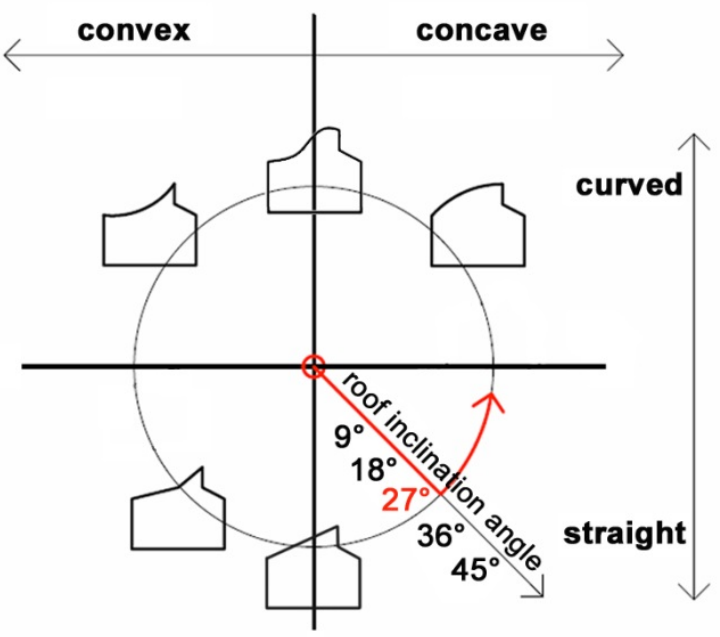

Fig. 2. Conceptual criteria for the selection of the leeward sawtooth roof geometries

a

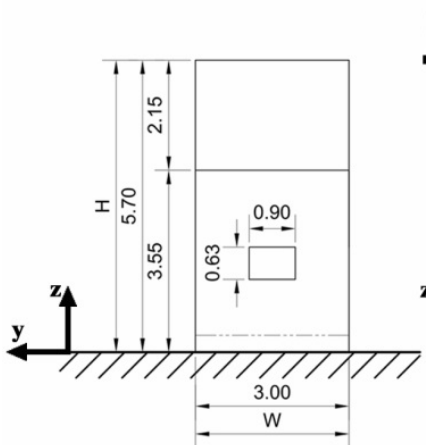

b

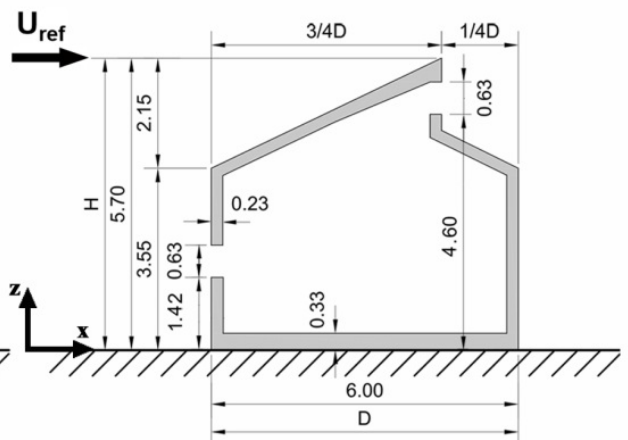

C

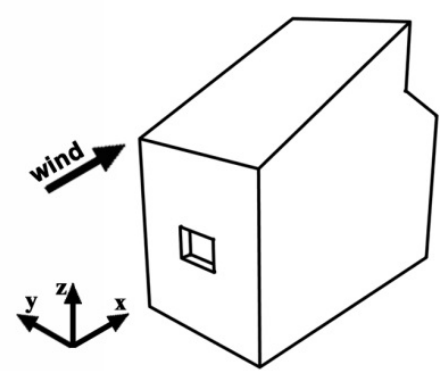

Fig. 3. Overview of dimensions of geometry A (dimensions in m). (a) Front view (upwind facade) with opening size and dimensions. (b) Vertical cross-section with opening size and dimensions. (c) Perspective view. The other roof geometries (B-E) have the same roof height, facade porosity (inlet-outlet opening size), building depth and width; however, they have diferent roof shapes and consequently diferent internal volumes. 
a

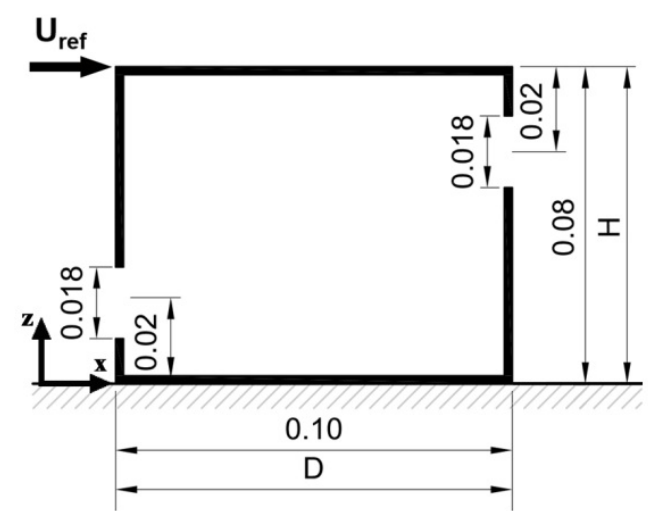

C

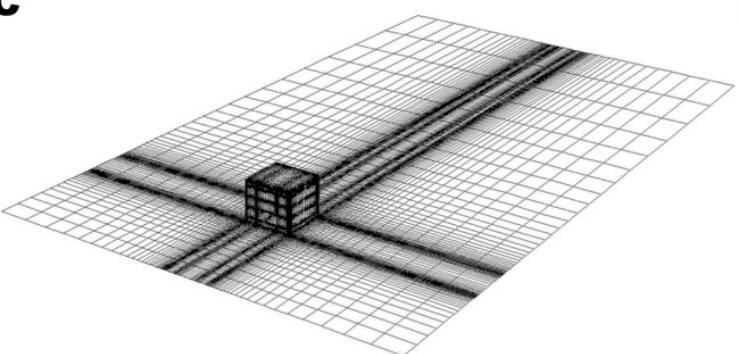

b
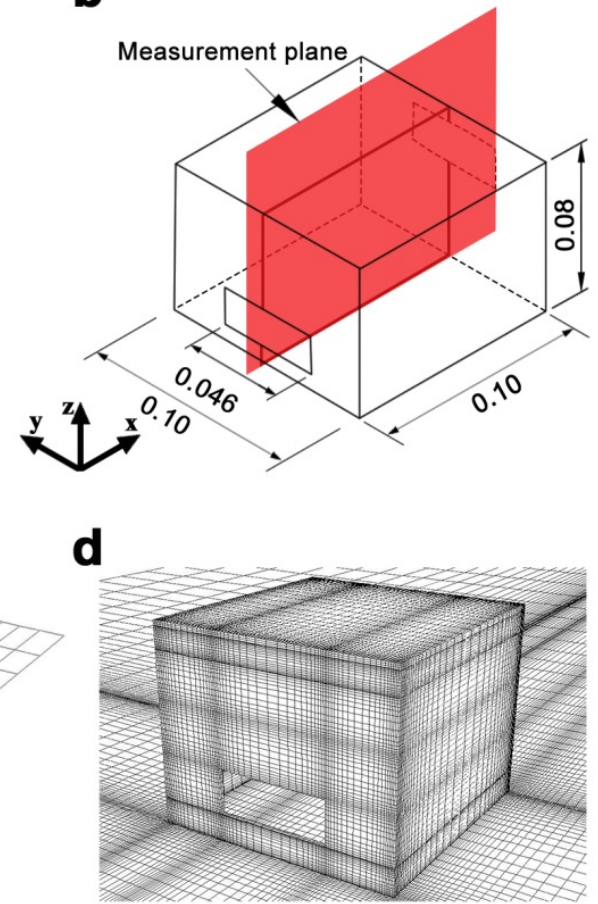

Fig. 4. (a) Vertical cross-section of the reduced-scaled building model as studied by Karava et al. (2011) with opening size and dimensions (in meter). (b) Perspective view indicating the measurement plane with dimensions (in meter). (c) View of the computational grid on the building and ground surfaces. (d) Close-up view of the grid (total number of cells: 770,540).
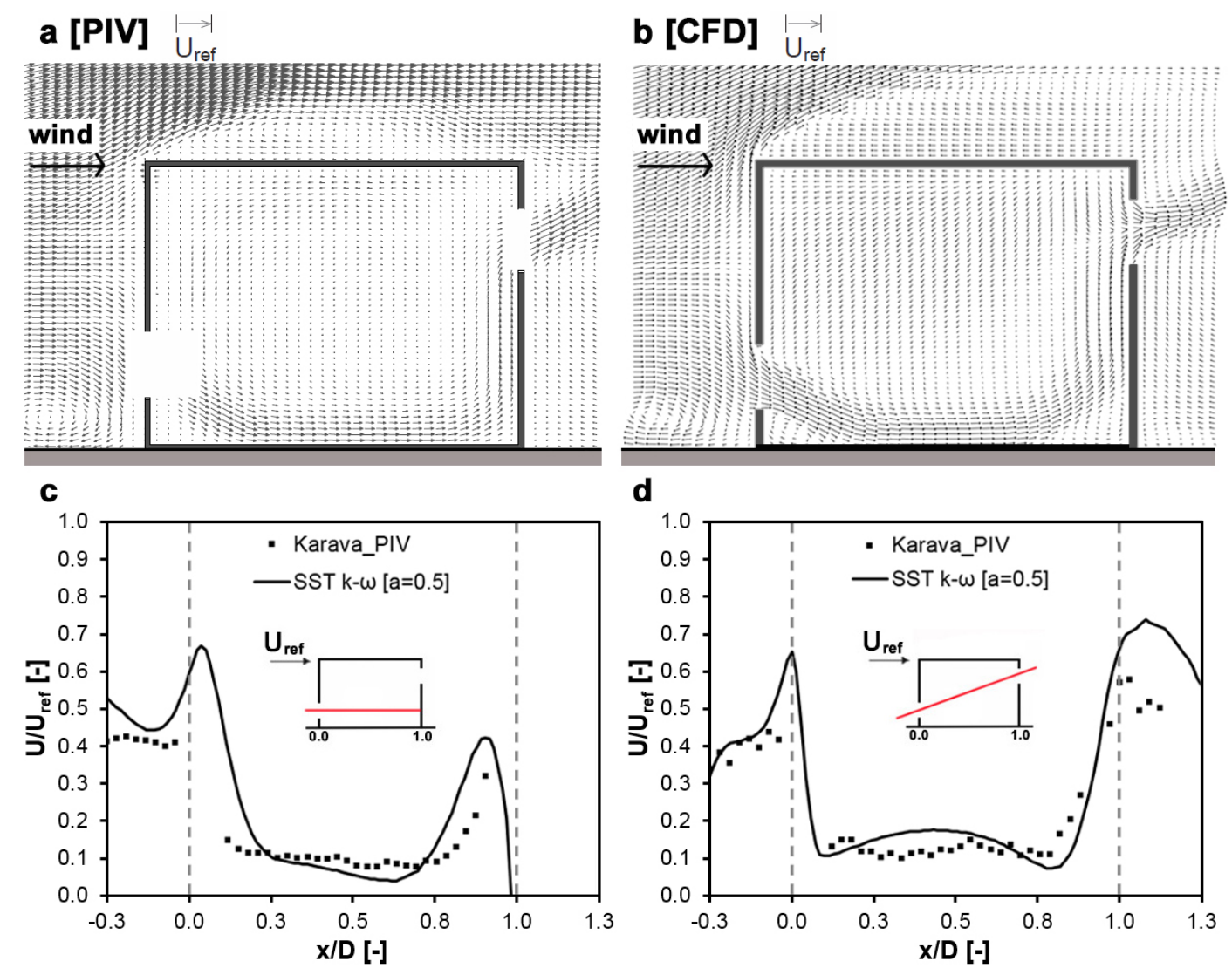

Fig. 5. (a,b) Comparison of the mean velocity in the vertical center plane obtained from: (a) PIV measurements (processed from Karava et al. (2011)); (b) CFD simulation. (c,d) Streamwise wind speed ratio U/U $\mathrm{U}_{\text {ref }}$ from PIV measurements and CFD simulation along: (c) horizontal line; and (d) diagonal line. 
a

b

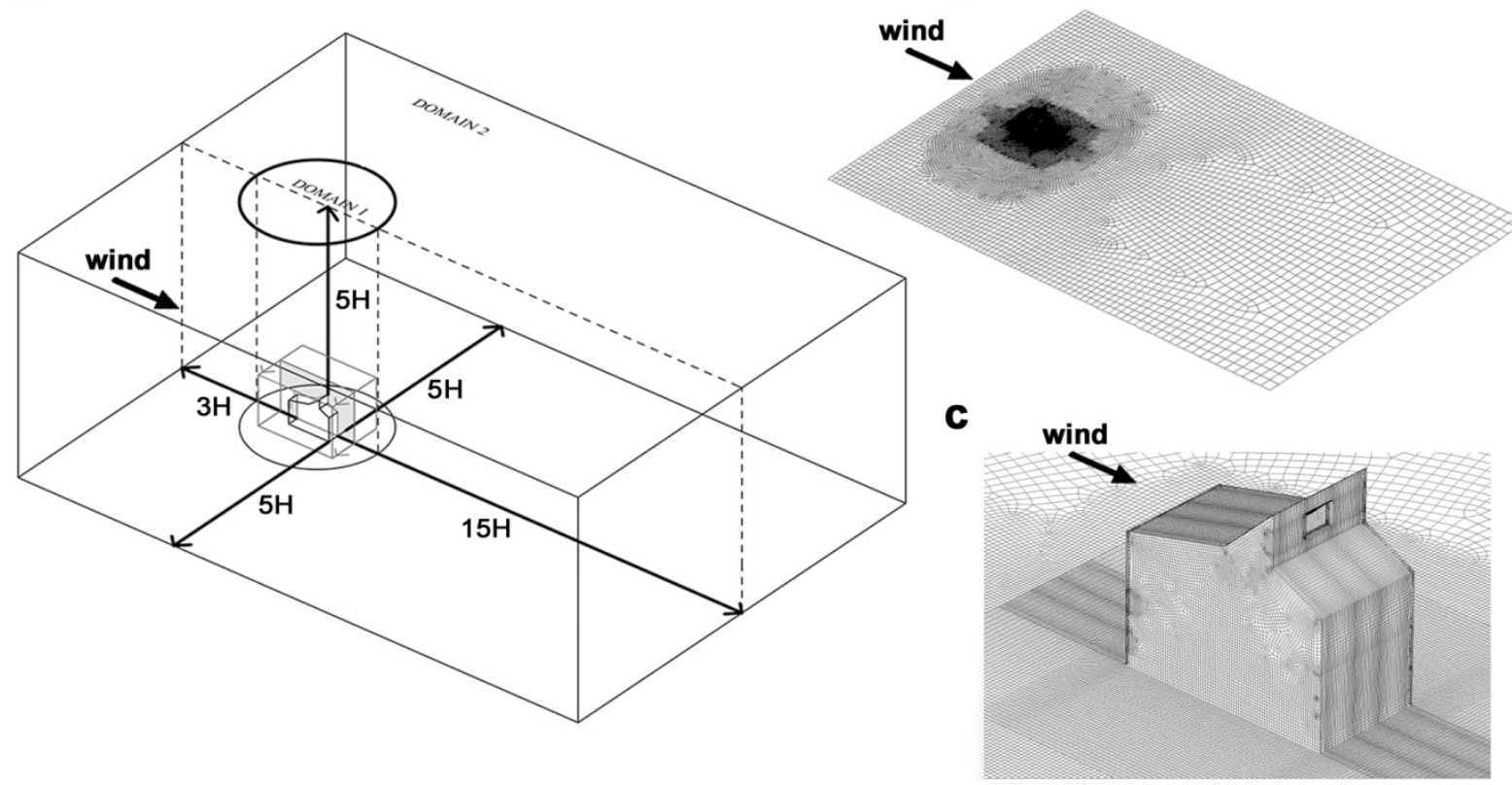

Fig. 6. (a) Computational domain and (b, c) basic grid for geometry D on building and ground surfaces (total number of cells: $1,961,524)$.

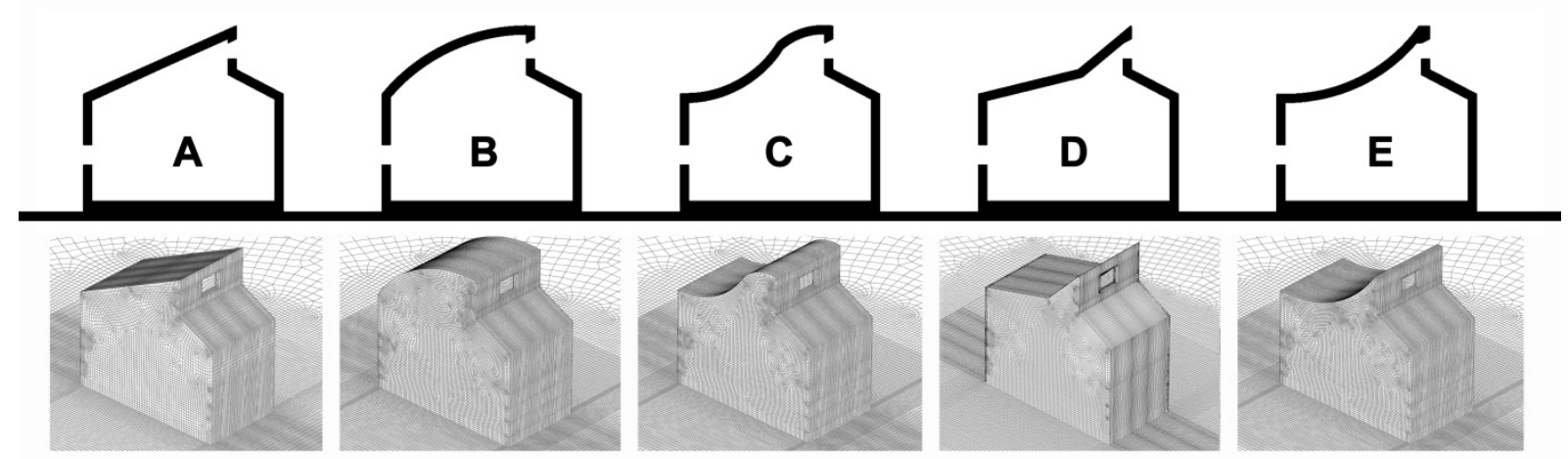

Fig. 7. Vertical cross-section of leeward saw-tooth roof buildings and part of the computational grid on the building and ground surfaces for each of the geometries. The number of cells for each geometry is based on a grid-sensitivity analysis for geometry D (1,961,524 cells) and varies slightly for each geometry.

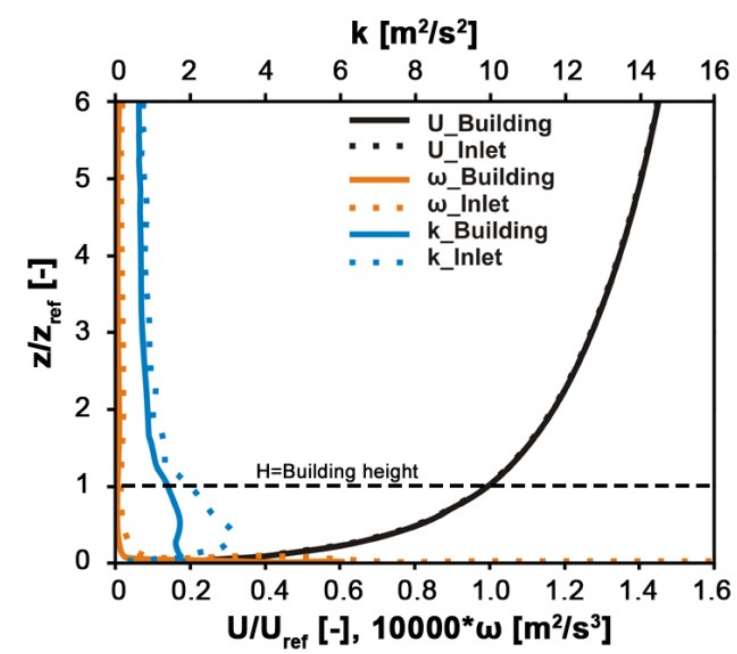

Fig. 8. Horizontal homogeneity analysis: profiles of mean wind speed (U), turbulent kinetic energy (k) and specific dissipation rate $(\omega)$ at the inlet (dashed line) and at the building position (solid line) in an empty domain. The height of the model $\left(\mathrm{H}=\mathrm{z}_{\mathrm{ref}}\right)$ is $5.7 \mathrm{~m}$. 


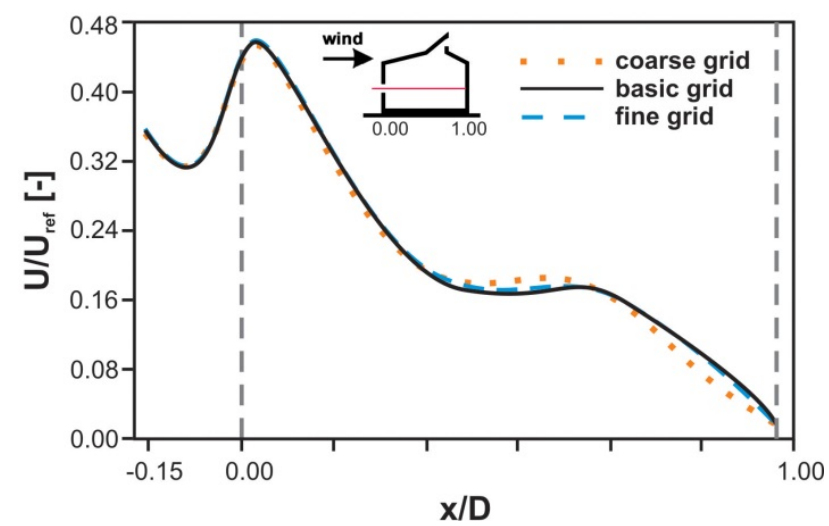

Fig. 9. Results of grid-sensitivity analysis: impact of the grid resolution on the dimensionless velocity magnitude $\left(|\mathrm{V}| / \mathrm{U}_{\text {ref }}\right)$ along a horizontal line through the middle of the windward opening.
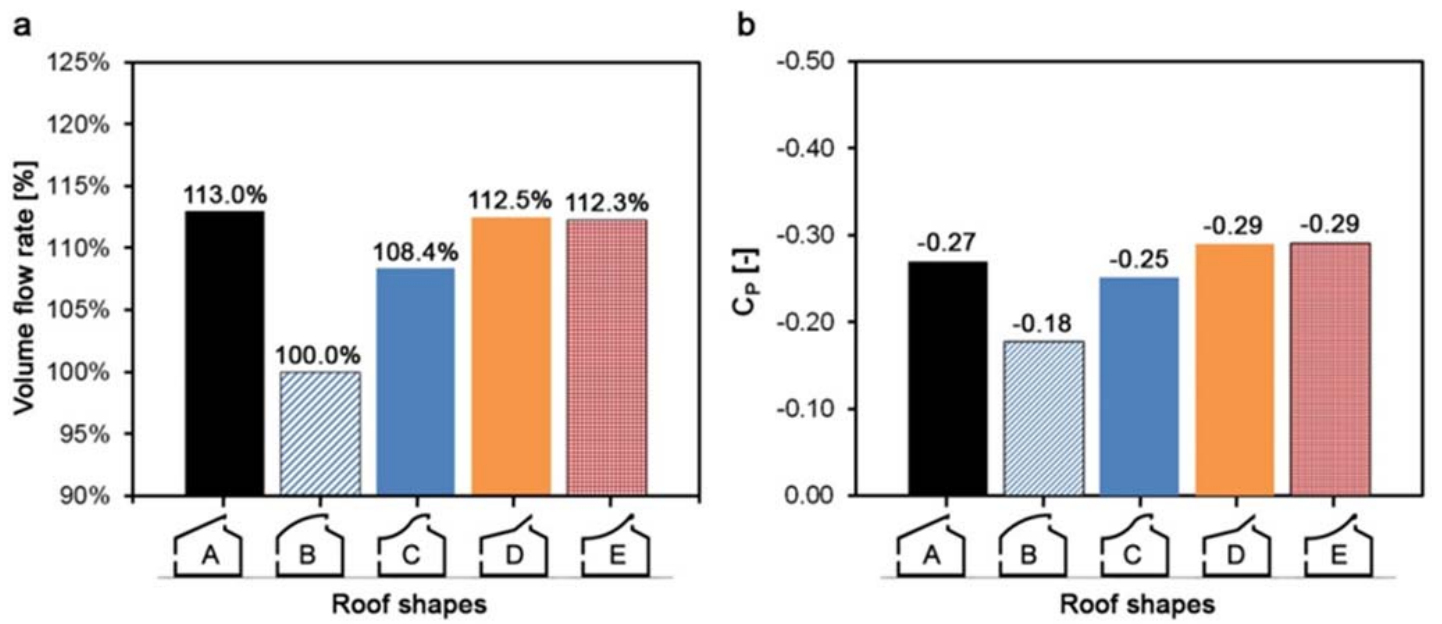

Fig. 10. Impact of roof geometry on the volume flow rate and the average pressure coefficient at the outlet opening for a normal wind incidence angle. (a) Volume flow rate. The volume flow rate for geometry B is taken as the reference case $(=100 \%)$. (b) Pressure coefficient $C_{P}$. 

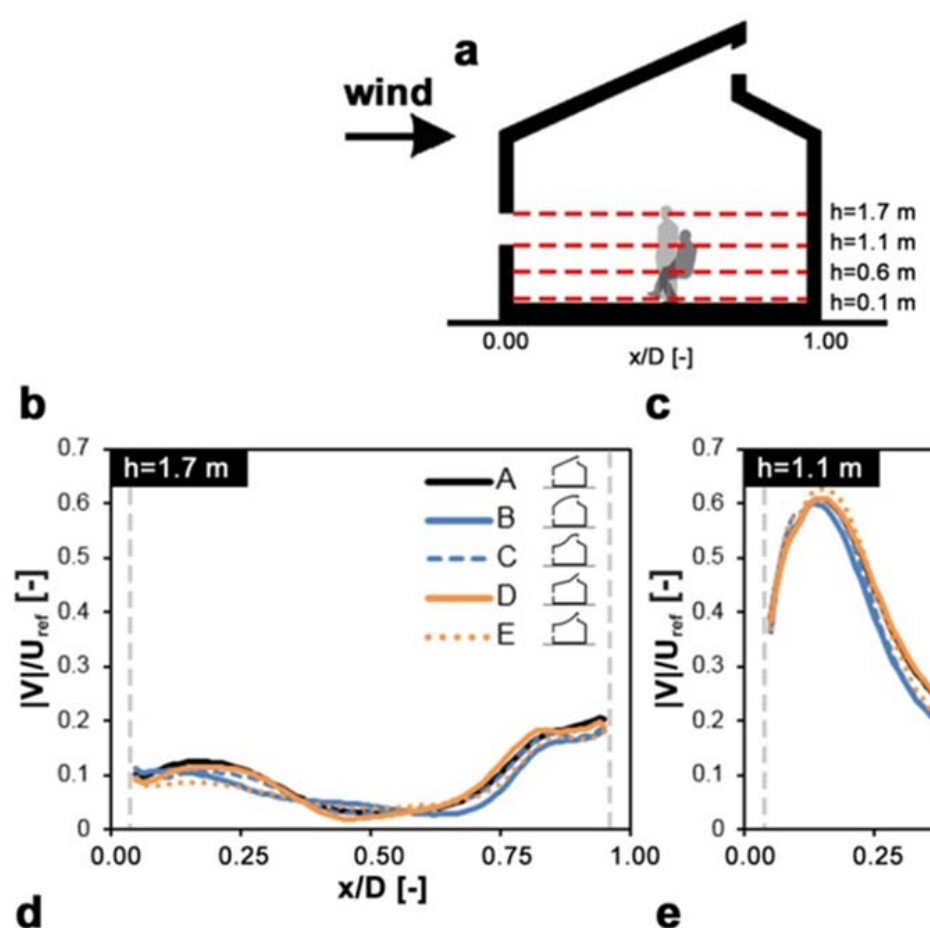

C

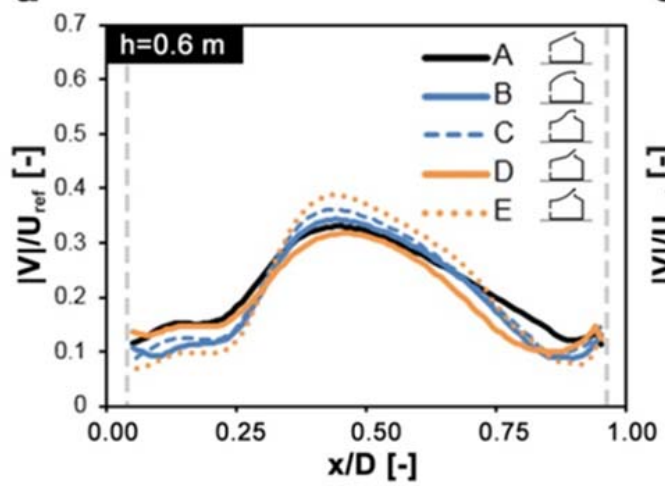

e
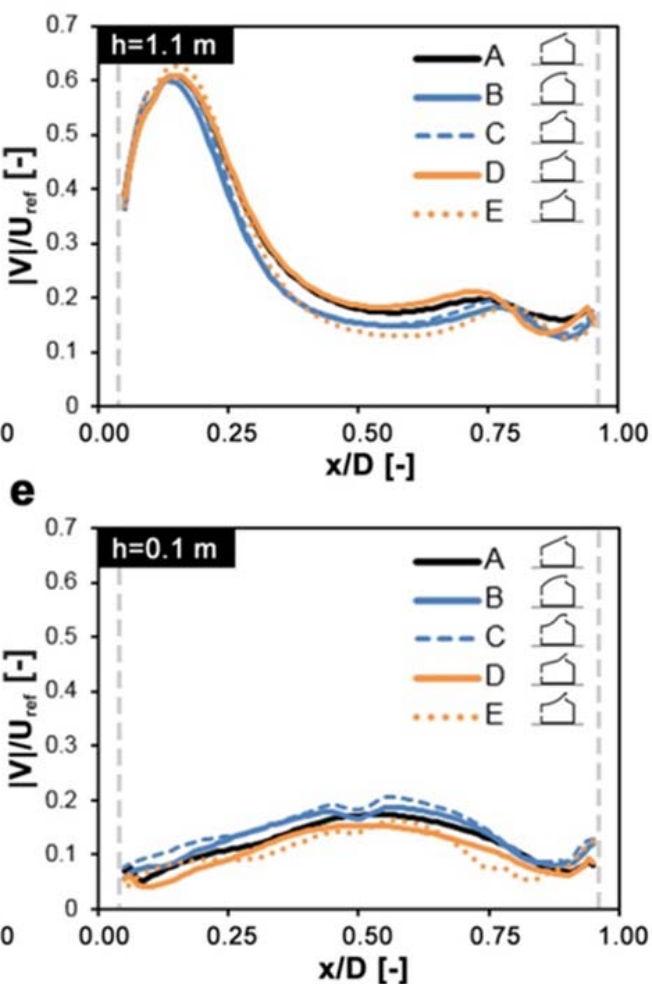

Fig. 11. Dimensionless velocity magnitude $\left(|\mathrm{V}| / \mathrm{U}_{\text {ref }}\right)$ along four horizontal lines at a height $\mathrm{h}$ above the floor. (a) Location of four lines. (b) $h=1.7 \mathrm{~m}$. (c) $\mathrm{h}=1.1 \mathrm{~m}$. (d) $\mathrm{h}=0.6 \mathrm{~m}$. (e) $\mathrm{h}=0.1 \mathrm{~m}$. The dashed vertical lines indicate the inner surfaces of the walls at the windward and leeward side of the building. 


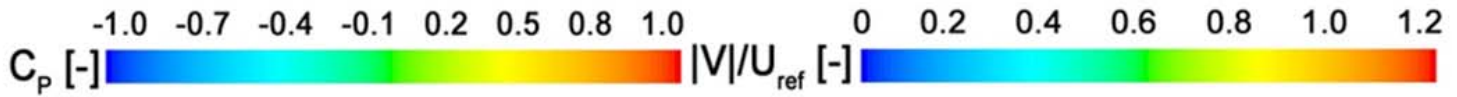

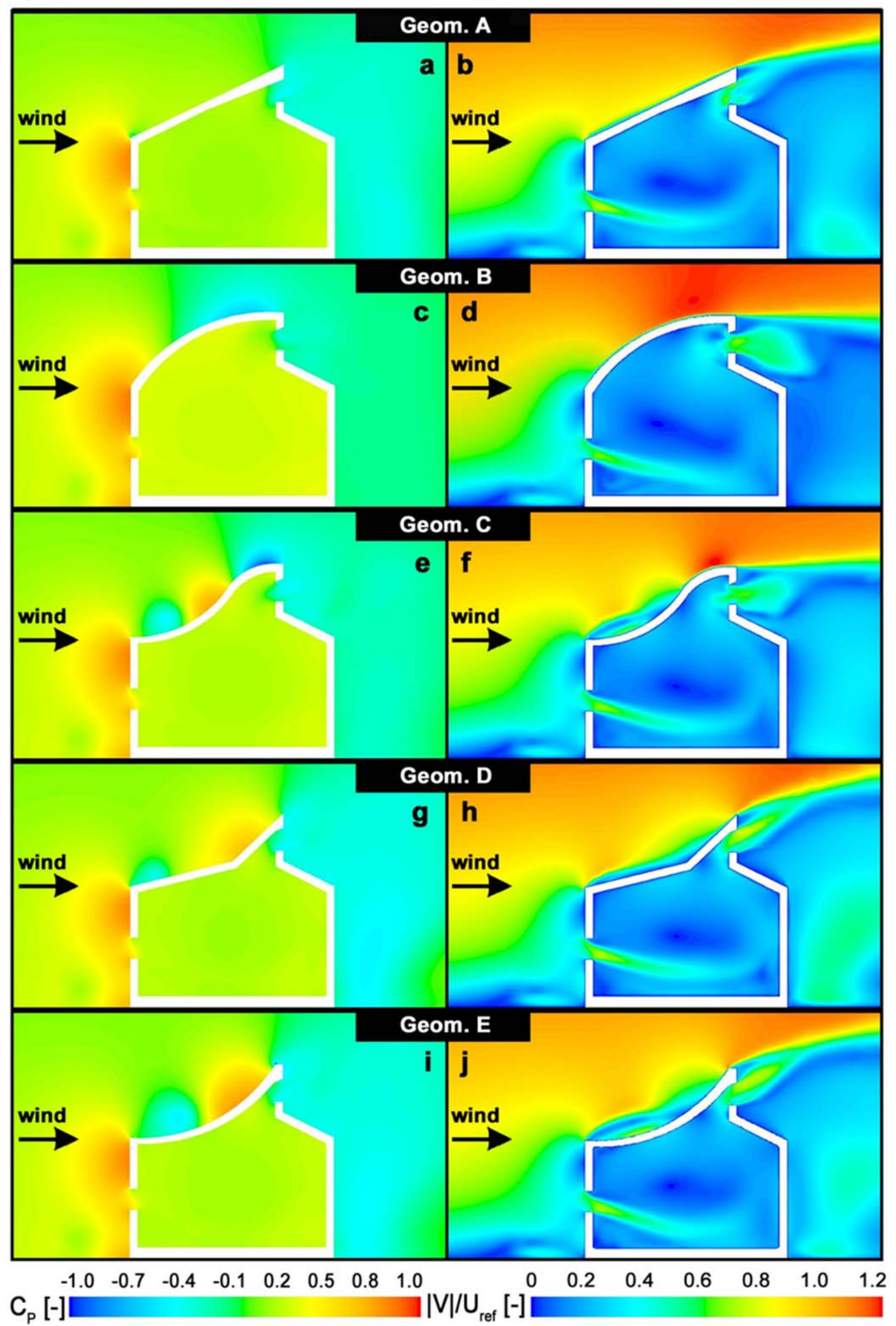

Fig. 12. Contour plot of the pressure coefficient $C_{P}(a, c, e, g, i)$ and the dimensionless velocity magnitude $\left(|V| / U_{\text {ref }}\right)$ $(b, d, f, h, j)$ in the vertical center plane for the five roof geometry cases. 


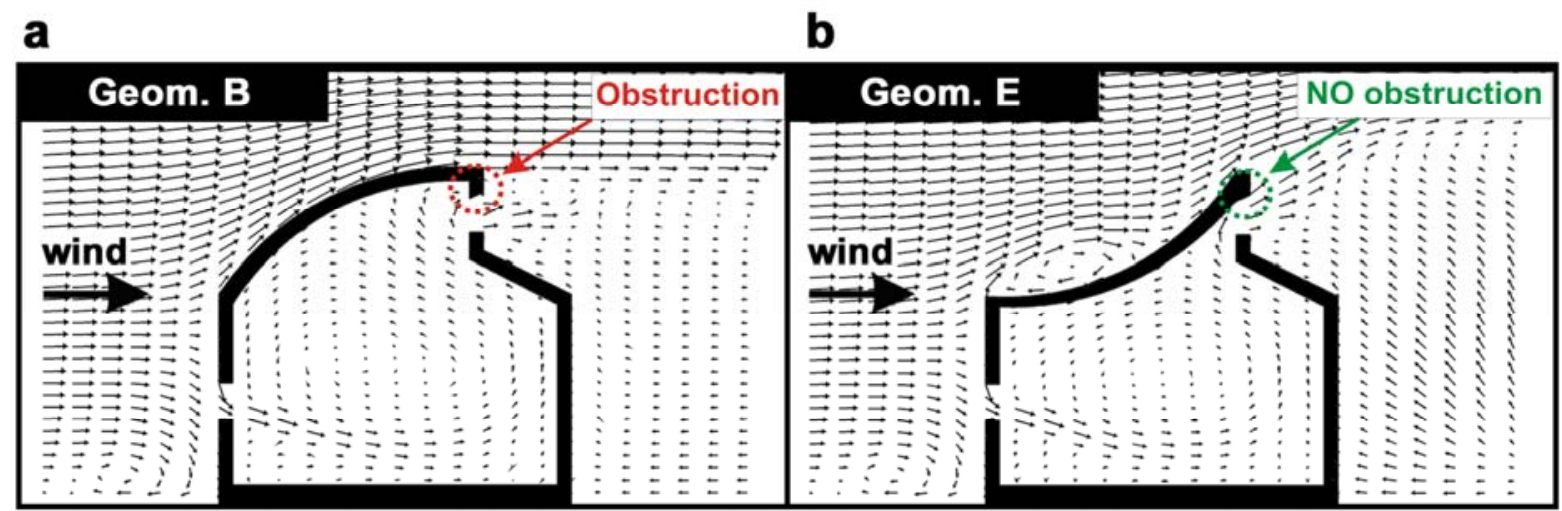

Fig. 13. Velocity vectors in the vertical center plane. (a) Geometry B. (b) Geometry E.

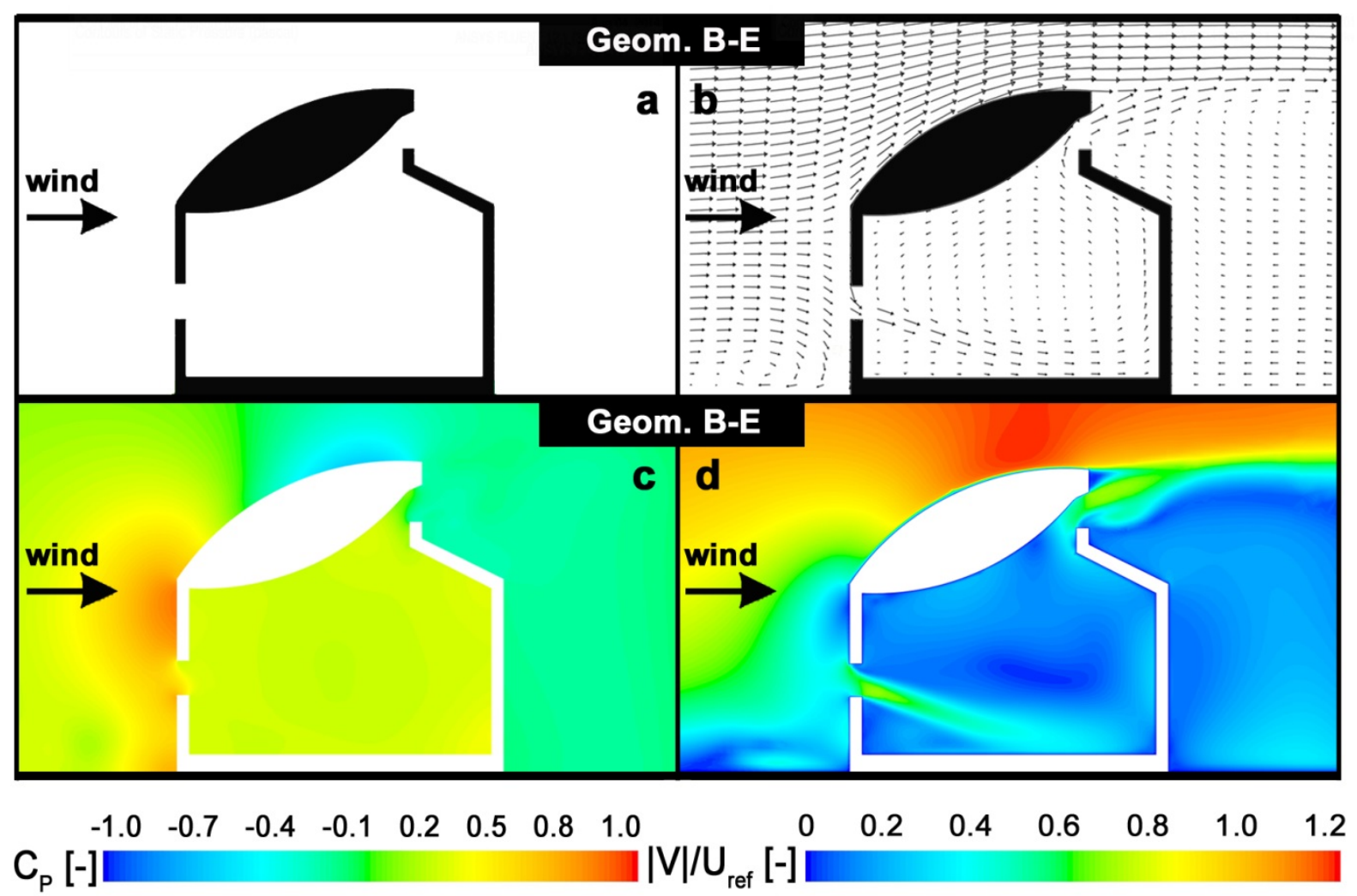

Fig. 14. (a) Schematic represenation of roof geometry B-E. (b) Velocity vectors in the vertical center plane. (c) Contours of pressure coefficient $C_{P}$ in the vertical center plane. (d) Contour plot of the dimensionless velocity magnitude $\left(|\mathrm{V}| / \mathrm{U}_{\mathrm{ref}}\right)$ in the vertical center plane. 

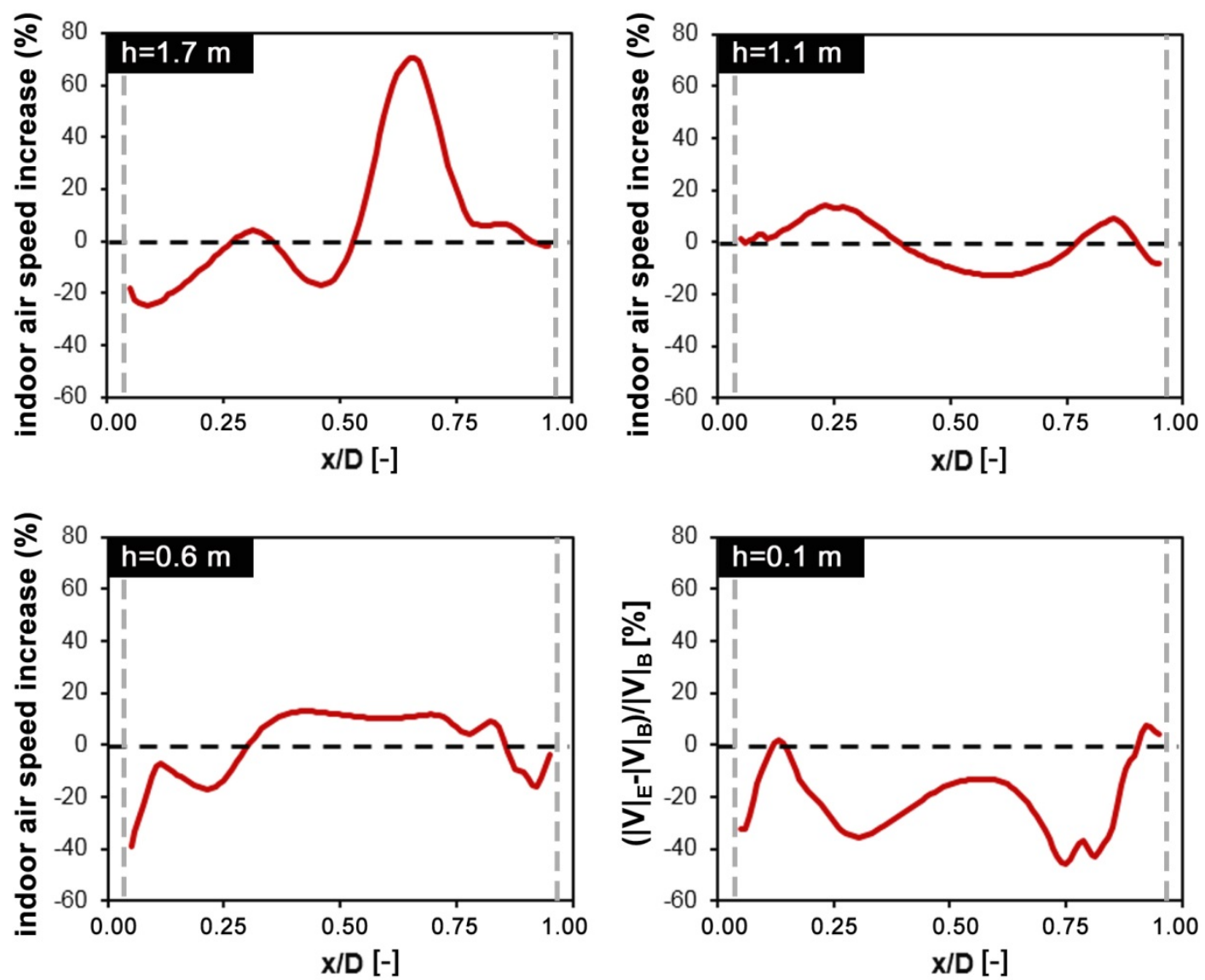

Fig. 15. Percentage increase of the indoor velocity magnitude $|\mathrm{V}|\left(\left(|\mathrm{V}|_{\mathrm{E}}-|\mathrm{V}|_{\mathrm{B}}\right) /|\mathrm{V}|_{\mathrm{B}}\right)$ along four horizontal lines for roof geometry E when compared to geometry B. (a) $h=1.7 \mathrm{~m}$. (b) $\mathrm{h}=1.1 \mathrm{~m}$. (c) $\mathrm{h}=0.6 \mathrm{~m}$. (d) $\mathrm{h}=0.1 \mathrm{~m}$. 